\title{
PENERAPAN MODEL KLARIFIKASI NILAI UNTUK MENINGKATKAN KETERAMPILAN PENGAMBILAN KEPUTUSAN TENTANG KONFLIK SOSIAL PADA PEMBELAJARAN IPS DI MTsN 2 CIREBON
}

\author{
Devi Bing Slamet ${ }^{1}$, Ratna Puspitasari ${ }^{2}$ \\ IAIN Syekh Nurjati Cirebon ${ }^{1,2}$ \\ devi.bingslamet@gmail.com;puspitasarinana72@gmail.com
}

\begin{abstract}
Abstrak
Model klarifikasi nilai adalah pendekatan pendidikan nilai yang membuat peserta didik dilatih untuk menemukan, memilih, menganalisis, memutuskan, mengambil sikap sendiri nilai-nilai hidup yang ingin diperjuangkan. Namun dalam pengamatan peneliti menemukan penerapan model yang ada di sekolah hanya model konvensional yang kurang penanaman nilai, sehingga siswa kurang memiliki keterampilan pengambilan keputusan. Tujuan umum penelitian ini adalah untuk meningkatkan keterampilan pengambilan keputusan tentang konflik pada mata pelajaran IPS $\mathrm{l}$ kelas VIII $\mathrm{H}$ pada pembelajaran IPS di MTsN 2 Cirebon.Penelitian ini merupakan Penelitian Tindakan Kelas (PTK). Subjek penelitiannya adalah siswa kelas VIII H di MTsN 2 Cirebon. Adapun teknik pengumpulan data yang digunakan yaitu observasi, tes, wawancara dan dokumentasi dan analisis datanya menggunakan data kuantitatif dan data kualitatif.Hasil penerapan model klarifikasi nilai dilihat dari aktivitas guru pada siklus 1 72\%, siklus 2 84\%, siklus 3 90\%. Keterampilan pengambilan keputusan tentang konflik sosial dilihat dari aktivitas siswa pada siklus 1 55\%, siklus 2 74\%, dan siklus 3 80\%. Peningkatan tes keterampilan pengambilan keputusan tentang konflik rata-rata kelas pada pra siklus 67 menjadi 73 pada siklus 1 ke siklus 277 kemudian siklus 3 81. Ketuntasan pada pra siklus 20\% kategori kurang terampil ke siklus I menjadi 45\% kategori cukup terampil, kemudian dari siklus II 75\% kategori terampil ke siklus III menjadi 87,5\% kategori sangat terampil. Simpulan model klarifikasi nilai meningkatkan keterampilan pengambilan keputusn tentang konflik sosial pada pelajaran IPS.
\end{abstract}

\section{Kata Kunci: Model Klarifikasi Nilai, Keterampilan Pengambilan Keputusan, Konflik Sosial}

\begin{abstract}
The value clarification model is a value education approach that enables learners to be trained to find, choose, analyze, decide, take on their own values of life that they want to strive for. But in the observation of the researchers found that the application of existing models in schools is only a conventional model that is less value investing, so that students lack the decision-making
\end{abstract}


skills. The general objective of this research is to improve conflict decisionmaking skills on IPS subjects l class VIII H on Social Studies lesson in MTsN 2 Cirebon. This research is a Classroom Action Research (PTK). The subject of the research is the students of class VIII $H$ in MTsN 2 Cirebon. The data collection techniques used are observations, tests, interviews and documentation and data analysis using quantitative data and qualitative data. The result of applying the value clarification model is seen from teacher activity in cycle 1 $72 \%$, cycle $284 \%$, cycle $390 \%$. Decision-making skills about social conflict are seen from student activities in cycle $155 \%$, cycle 2 74\%, and cycle $380 \%$. Improved test of decision-making skill on average class conflict in pre cycle 67 to 73 in cycle 1 to cycle 277 then cycle 3 81. Completeness on pre cycle 20\% less skilled category to cycle I to 45\% skilled enough category, then from cycle II $75 \%$ skilled category to cycle III to $87.5 \%$ highly skilled category. The conclusion of the value clarification model improves decision-making skills about social conflict in IPS lessons

\section{Keywords: Value Clarification Model, Decision Making Skill, Social Conflict}

\section{A. Pendahuluan}

\section{Latar Belakang Masalah}

Pendidikan di Indonesia memiliki landasan hukum pada UU No. 20 Tahun 2003 tentang SISDIKNAS menjelaskan bahwa Pendidikan merupakan usaha sadar dan terencana untuk mewujudkan suasana belajar dan proses pembelajaran agar peserta didik secara aktif mengembangkan potensi dirinya untuk memiliki kekuatan spiritual keagamaan, pengendalian diri, kepribadian, kecerdasan, akhlak mulia, serta keterampilan yang diperlukan dirinya, masyarakat, bangsa, dan negara. Pada dasarnya pendidikan merupakan usaha, pengaruh, perlindungan dan bantuan yang diberikan kepada anak sebagai proses pendewasan diri.

Pendidikan dapat dilakukan melalui proses belajar dan pembelajaran sehingga dapat mencapai dari tujuan pendidikan itu sendiri. Witherington (Siregar, 2011: 4) menjelaskan pengertian belajar merupakan suatu perubahan di dalam kepribadian yang menyatakan diri sebagai suatu pola baru dari reaksi berupa kecakapan sikap, kebiasaan kepribadian atau suatu pengertian.Dengan demikian dapat dipahami bahwa orang yang dikatakan telah belajar dapat dilihat dari perubahan tingkah laku yang dimiliki.

Penerapan pembelajaran IPS di sekolah dewasa ini kurang sesuai dengan konsep dasar maupun tujuan yang diharapkan pada pendidikan 
IPS dan pendidikan nasional. Hal ini sama dengan yang di temukan peneliti melalui wawancara kepada guru pamong dan observasi dimana pembelajaran IPS yang diterapkan di sekolah MTsN 2 Cirebon hanya menekankan pada ranah kognitif saja, sehingga proses internalisasi nilai dan norma yang harusnya ada dalam pembelajaran IPS kurang tersentuh.Hal ini disebabkan guru masih menggunakan metode konvensional dalam pembelajaran IPS sedangkan materi dalam pembelajaran IPS sangat banyak.

Pembelajaran IPS yang tekstual dan menggunakan model konvensional menjadikan siswa sangat kekurangan semangat dalam pembelajaran IPS.Selain itu, dalam pembelajaran siswa masih belum bisa mengatasi permasalahan- permasalahan yang diangkat oleh guru dalam pembelajaran.siswa masih belum memiliki keterampilan untuk mengatasi permasalahan dan kurang mampu untuk mengambil keputusan dalam penyelesaian permasalah.. sehingga dalam tes yang dilakukan peneliti untuk mengukur keterampilan pengambilan keputusan siswa tentang sebuah konflik masih rendah di mana yang memenuhi hanya 20\% dari jumlah siswa 40 dengan KKM pelajaran IPS di MTsN 2 Cirebon yaitu 75.

Berdasarkan permasalahan- permasalahan yang ditemukan peneliti di MTsN 2 Cirebon. Permasalahan persebut merupakan permasalahan yang dapat di selesaikan dengan proses pembelajaran yang memiliki penanaman nilai serta dapat meningkatkan keterampilan pengambilan keputusan. Proses pembelajaran penanaman nilai dapat menggunakan model klarifikasi nilai. Oleh karena itu, peneliti menawarkan solusi dengan melakukan penelitian tindakan kelas yang berjudul “Penerapan Model Klarifikasi Nilai Untuk Meningkatkan Keterampilan Pengambilan Keputusan Tentang Konflik Sosial pada pembelajaran IPS di MTsN 2 Cirebon”.

\section{Rumusan Masalah}

Berdasarkan hasil tersebut, maka permasalahan dalam penelitian ini dapat dirumuskan sebagai berikut :

a. Bagaimana penerapan model klarifikasi nilai pada pembelajaran IPS kelas VIII di MTsN 2 Cirebon? 
b. Bagaimana keterampilan pengambilan keputusan tentang konflik sosial dalam penerapan model klarifikasi nilai pada pembelajaran IPS kelas VIII di MTsN 2 Cirebon?

c. Bagaimana Peningkatkan hasil keterampilan pengambilan keputusan tentang konflik sosial dengan penerapan model klarifikasi nilai pada pembelajaran IPS kelas VIII di MTsN 2 Cirebon?

\section{Tujuan Penelitian}

Sesuai dengan rumusan masalah diatas, tujuan penelitian tindakan kelas ini adalah sebagai berikut:

a. Menerapkan model klarifikasi nilai pada pembelajaran IPS kelas VIII di MTsN 2 Cirebon.

b. Mengetahui keterampilan pengambilan keputusan tentang konflik sosial dalam penerapan model klarifikasi nilai pada pembelajaran IPS kelas VIII di MTsN 2 Cirebon.

c. Mengetahui Peningkatkan hasil keterampilan pengambilan keputusan tentang konflik sosial dengan penerapan model klarifikasi nilai pada pembelajaran IPS kelas VIII di MTsN 2 Cirebon.

\section{B. KAJIAN TEORI}

\section{Pengertian Model Klarifikasi Nilai (Value Clarification Technique- VCT)}

Model klarifikasi nilai (Value Clarification Technique-VCT) adalah pendekatan pendidikan nilai yang membuat peserta didik dilatih untuk menemukan, memilih, menganalisis, memutuskan, mengambil sikap sendiri nilai-nilai hidup yang ingin diperjuangkan.Model klarifikasi nilai VCT memberi penekanan pada usaha membantu siswa dalam mengkaji perasaan dan perbuatan sendiri, untuk meningkatkan kesadaran mereka tentang nilai-nilai mereka sendiri (Sutarjo, 2013: 141-142).

Berdasarkan pengertian di atas, maka dapat disebutkan bahwa model klarifikasi nilai adalah suatu model klarifikasi nilai yang terletak pada proes penilaian yang bertujuan untuk menata situasi agar siswa mendapatkan nilai-niai mereka sendiridengan cara terlibat dalam memilih, menghargai 
dan berbuat dalam suatu tindakan dan dapat mengambil keputusannya sendiri dengan menyelaraskan dengan niali-nilai baru yang ditanamkan.

\section{Pengertian Konflik}

Kata konflik menurut bahasa Yunani configere, conflictm yang berarti saling berbenturan.Arti kata ini menunjukan pada semua bentuk benturan, tabrakan, ketidaksesuaian, ketidakserasian, pertentangan, perkelahian, oposisi, dan interaksi-interaksi yang antagonis bertentangan.Sehingga konflik merupakan sebuah pertentangan atau benturan yang terjadi di masyarakat akibat interaksiinteraksi yang saling bertentangan (kartono,1991: 213 dalam Soetopo 2012: 267).

Berdasarkan uraian di atas dapat dijelaskankan bahwa konflik adalah suatu pertentangan dan ketidaksesuaian kepentingan, tujuan, dan kebutuhan dalam situasi formal, sosial, psikologi, sehingga menjadi antagonis, ambivalen, dan emosional.

\section{Pengertian Pendidikan IPS}

Konsep dasar ilmu pengetahuan sosial telah dikemukakan oleh Sumantri (2001: 89) dalam Gunawan (2013: 17) yaitu IPS merupakan suatu program pendidikan dan bukan sub-disiplin ilmu sendiri, sehingga tidak akan ditemukan baik dalam nomenklatur filsafat ilmu, disiplin ilmu-ilmu sosial, maupun ilmu-ilmu sosial. Ilmu Pengetahuan Sosial (IPS) sebagai kajian akademik merupkan perkembangan ilmu pengetahuan yang berhubungan dengan bidang prakik pendidikan komitmen masyarakat yang ingin mengembangkan pengetahuan dan humaniora yang dikemas secara psikologis untuk tujuan pendidikan sehingga melahirkan IPS.Dapat dipahami bahwa IPS merupakan sinthesa kajian pendidikan dan kajian sosial serta humaniora program pendidikan di tingkat sekolah.

\section{Pengertian Keterampilan Pengambilan Keputusan}

Pengambilan keputusan atau decision makingmenurut Rofiq (2015:178) merupakan proses penyeleksian diantara pilihan-pilihan untuk mengevaluasi kesempatan yang ada. Pilihan-pilihan yang ada kemudian diseleksi dengan mempertimbangkan segala kemungkinan yang terjadi hingga pada akhirnya 
terbentuk suatu keputusan.Hampir setiap hari manusia selalu memecahkan masalah dan membuat keputusan, baik di rumah, di kelas, atau dimanapun.

Berdasarkan uraian di atas dapat dipahami bahwa proses pengambilan keputusan tidak terjadi secara kebetulan dan asal, tetapi melalui proses rasional. Pengambilan keputusan harus dilakuakan dengan memperhatikan

1) proses pengambilan keputusan dilakukan dengan sengaja, 2) pengambilan keputusan menggunakan pendekatan sistematis, 3) pengambilan keputusan untuk pemecahan masalah, 4) pengambilan keputusan harus berdasarkan fakta dan data, 5) keputusan yang baik merupakan hasil analisis yang matang.

\section{Pengertian PTK}

Hopkins (1993) dalam Arifin (2011: 97) menjelaskan mengenai penngertian PTK secara singkat, bahwa penelitian tindakan kelas adalah penelitian untuk perubahan dan perbaikan yang dilakukan diruang kelas serta penelitian ini menggabungkan prosedur penelitian dengan kegiatan substansif.

Berdasarkan penjelasan di atas, maka dapat dijelaskan bahwa penelitian tindakan kelas adalah penelitian kualitatif yang dilakukan oleh guru sendiri ketika mendapatkan permasalahan dalam pembelajaran dan mencarikan solusinya dalam upaya memperbaiki kualitas pembelajaran

\section{Kajian Penelitian Relevan}

Penelitian pertama yang relevan dengan penelitian peneliti yaitu "pengaruh model klarifikasi nilai berbasis jurnal terhadap proses internalisasi nilai dalam pembelajaran IPS” yang diteliti oleh Neni Setia Arini pada tahun 2014 yang berbentuk penelitian tesis untuk menyelesaikanprogram Magister. Penelitian yang dilakukan Neni bertempat di SMP N 1 Kab.Cianjur.

a. Persamaan

Penelitian ini sama-sama meneliti tentang model klarifikasi nilai, jenjang lokasi penelitian, dan sama-sama membahas mengenai pembelajaran IPS.

b. Perbedaan

Penelitian ini menggunakan metode penelitian kuantitatif dengan desain kuasi eksperiemen dan variabel 2 internalisasi nilai.Sedang peneliti 
menggunkan metode penelitian tindakan kelas desai Kemmis dan Mc Tagart dan variabel 2 keterampilan pengambilan keputusan.

\section{METODOLOGI}

\section{Jenis Penelitian}

Jenis Penelitian yang dilakukan oleh peneliti mengacu pada metode penelitian tindakan kelas atau PTK.Penelitian tindakan kelas merupakan penelitian kualitatif yang dilakukan oleh guru sendiri ketika mendapat permasalahan dalam pembelajaran untuk ditemukan solusinya. Secara umum menurut Sudaryono (2014: 75) tujuan dari penelitian tindakan kelas yaitu untuk memecahkan masalah, memperbaiki kondisi, mengembangkan dan meningkatkan mutu pembelajaran

\section{Desain Penelitian}

Desain penelitian tindakan kelas yang digunakan peneliti yaitu dengan mengikuti desain Model Penelitian Tindakan Kelas dari Kemmis dan Mc Taggart.Menurut Sudaryono (2014: 162) dalam pelaksanaan penelitian refleksi diri yang dimulai dengan rencana (planning), tindakan (acting), pengamatan (observing), refleksi (reflecting), dan perencanaan kembali yang merupakan dasar untuk suatu ancang-ancang pemecahan masalah.

\section{Lokasi dan Waktu Penelitian}

Penelitian tindakan kelas ini dilakukan di kelass VIII H MTs Negeri 2 Cirebon Kecamatan Cirebon Provinsi Jawa Barat.Penelitian ini dilakukan pada semester genap tahun pelajaran 2017/2018.Pelaksanaan penelitian dilakukan dari minggu ke-3 bulan Januari sampai dengan minggu ke-2 bulan Februari 2018.

\section{Teknik Pengumpulan Data}

Dalam tenik pengumpulan data penelitian menggunakan beberapa teknik antara lain teknik observasi, tes, wawancara, dan dokumentasi.

\section{Instrument Penelitian}

Instrument pengumpulan data merupakan alat yang digunakan dalam sebuah penelitian untuk mengambil data yang dibutuhkan dan sebagai penunjang dalam melakukan teknik pengumpulan data.Dalam penelitian ini 
menggunakan instrument pengumpulan data berupa tesberupa pertanyaanpertanyaan dan presentasi dari cerita VCT-GAMES dengan mengklarifikasi konflik pada materi yang berupa essay untuk mengukur keterampilan pengambilan keputusan siswa pada saat pembelajaran; lembar observasi aktivitas guru dan siswa, dan pedoman wawancara pra siklus dan pasca siklus.

\section{Analisis Data}

Analisis data merupakan tahap menganalisis data yang telah diperoleh dalam sebuah tindakan dalam penelitian tindakan kelas.

\section{a. Data Kuantitatif}

Data kuantitatif merupakan data berupa angka-angka dari hasil penelitian tindakan kelas yang dilakukan oleh peneliti dengan analisis statistik.Penelitian ini menggunakan teknik pengumpulan data observasi dan tesadalah sebagai berikut:

1) Rumus untuk menganalisis hasil tes

a) Skor/nilai rata-rata $=\frac{\text { jumlah nilai siswa }}{\text { Jumlah siswa }}$

b) Persentase tuntas belajar $=\frac{\text { jumlah siswa tuntas belajar }}{\text { Jumlah siswa }} \times 100 \%$

c) Skor maksimal = jumlah soal $\mathrm{x}$ bobot soal (Riduan, 2007: 23)

Kategori keterampilan pengambilan keputusan siswa

diklasifikasikan dalam bentuk \% dengan klasifikasi sebagai berikut:

Sangat Terampil $=75<\mathrm{x} \leq 100$; Terampil $=50<\mathrm{x} \leq 75$; Cukup

Terampil $=25<\mathrm{x} \leq 50$; Kurang Terampil $=\mathrm{x} \leq 25$

(Adaptasi Dikdasmen, 2016 dalam Muslimah, Erni, dkk, 2017)

2) Rumus menganalisis lembar observasi keaktifan guru dan siswa

a) Persentasi aktifitas guru $=\frac{\text { perolehan skor } \mathrm{x} 100 \%}{\text { Skor maksimal }}$

b) Persentasi aktifitas siswa $=\frac{\text { perolehan skor } \times 100 \%}{\text { Skor maksimal }}$

Setelah dihitung kemudian hasilnya diklasifikasikan sesuai dengan klasifikasi, adapun klasifikasi tersebut yaitu sebagai berikut:

Sangat baik = bila 86-100\% ; Baik = bila 76\% - 85\%; Cukup = bila 60\% -

75\%; Kurang = bila 55\% - 59\%; Tidak baik = bila 0\% - 54\%

(Arikunto, 2006: 109) 


\section{b. Data Kualitatif}

Data kuantitatif merupakan data berupa informasi yang memberikan gambaran mengenai ekspresi siswa dalam pembelajaran yang dapat diteliti melalui analisis kualitatif (Kunandar, 2013: 128). Dari penjelasan diatas peneliti akan menganalisis data-data kualitatif melalui analisis terhadap data-data dari wawancara dan studi dokumentasi.

\section{HASIL PENELITIAN DAN PEMBAHASAN}

Hasil penelitian yang diperoleh selama pelaksanaan tindakan dimulai dari pra siklus sampai siklus 3, menunjukan bahwa penerapan model klarifikasi nilai pada materi keunggulan dan keterbatasan antar-ruang dan pengaruhnya terhadap kegiatan ekonomi, sosial, budaya di Indonesia dan Asean dikelas VIII H MTs Negeri 2 Cirebon dapat meningkatkan keterampilan pengambilan keputusan Tentang Konflik. Model klarifikasi nilai ini merupakan pembelajaran yang efektif untuk menyelesaikan konflik pada mata pelajaran IPS seperti pada materi keunggulan dan keterbatasan antar-ruang dan pengaruhnya terhadap kegiatan ekonomi, sosial, budaya di Indonesia dan Asean. Pembelajarandi kelas menjadikan siswamampu mengklarifikasi nilaidan meningkatkan aktivitas belajar siswa dan keterampilan pengambilan keputusan siswa proses pembelajaran. Hal ini karena siswa telah mampu mengklarifikasi nilai hingga dapat mengambil keputusan dalam konflik.

Aktivitas siswa dalam proses pembelajaran meningkat, dapat terlihat dari semakin meningkatnya aktivitas siswa dalam proses pembelajaran berlangsung di dalam kelas. Model krarifikasi nilai membantu kepada peserta didikmengindentifikasikan nilai yang terbaik dalam mengatasi konflik, Siswa mulai berani untuk menganalisis konflik dan mengklarifikasi nilai sehingga mampu menganalisis pilihan yang akhirnya membuat keputusan sebagai penyelesaian konflik.Hal ini sesuai dengan kelebihan model klarifikasi nilai yaitu menurut Sutarjo (2013: 150) adalah memberi penekanan pada usaha membantu seseorang atau peserta didik dalam mengkaji perasaan dan perbuatannya sendiri, meningkatkan kesadaran mereka tentang nilai-nilai mereka sendiri dan mendorongnya untuk membentuk sistem nilai 
mereka sendiri serta mempraktikkannya dalam kehidupan sehari-hari. Selain itu, kelebihan dari model klarifikasi nilai adalah Memberi pengetahuan bagi peserta didik untuk berlatih mengkomunikasikan keyakinan, nilai hidup,cita- cita pribadi pada teman sejawat; berlatih berempati pada teman lain bahkan yang mungkin berbeda keyakinan; berlatih memecahkan persoalan dilema moral; berlatih untuk setuju atau menolak keputusan kelompok; berlatih terlibat dalam membuat keputusan.

Berdasarkan pengamatan pada siklus 1 aktivitas guru pada dalam menerapkan model klarifikasi nilai memperoleh persentase $72 \%$ dikategorikan cukup. Dan hasil keterampilan pengambilan keputusan siswa dilihat dari aktivitas siswa yang memperoleh persentase 55\% dikategorikan kurang. Hasil tes keterampilan pengambilan keputusan siswa menunjukan peningkatan skor rata-rata kelas dari pra siklus yaitu 67 menjadi 73 serta ketuntasan belajar dari pra siklus 20\% kategori kurang terampil menjadi 45\% kategori cukup terampil. Hal ini menunjukan hasil yang kurang sehingga peneliti dan observer merencanakan siklus berikutnya.

Pada pelaksanaan siklus 2 peneliti melakuakan perencanaan ulang sebagai tindak lanjut siklus 1. Hasil pengamatan pada nenerapan model klarifikasi nilai aktivitas mengajar guru mengalami peningkatan dari siklus 1 yaitu 72\% menjadi 84\% dengan kategori baik. Dan hasil keterampilan pengambilan keputusan siswa dilihat dari aktivitas siswa yang memperoleh peningkatan dari persentase 55\% pada siklus 1 menjadi 74\% pada siklus 2 dikategorikan cukup.

Kemudian Hasil tes keterampilan pengambilan keputusan siswa menunjukan peningkatan skor rata-rata kelas dari siklus1 yaitu 73 menjadi 77 serta ketuntasan belajar dari siklus 1 45\% kategori cukup terampil menjadi 75\% kategori terampil pada siklus 2. Siklus 2 mendapatkan hasil yang lebih baik dari siklus 1 namun masih memiliki kekurangan yaitu aktivitas siswa yang masih dalam kategori cukup. Sehingga dilakukan siklus ke 3 untuk melakukan perbaikan. Siklus 3 merupakan tindak lanjut dari siklus 2 sehingga hasil pengamatan pada siklus 3 menunjukan aktivitas mengajar guru mengalami peningkatan dari siklus 2 yaitu 84\% menjadi 90\% dengan 
kategori sangat baik. Dan hasil keterampilan pengambilan keputusan siswa dilihat dari aktivitas siswa yang memperoleh peningkatan dari persentase 74\% pada siklus 2 menjadi 80\% dikategorikan baik. Kemudian Hasil tes keterampilan pengambilan keputusan siswa menunjukan peningkatan skor rata-rata kelas dari siklus 2 yaitu 77 menjadi 81 serta ketuntasan belajar dari siklus 2 adalah 75\% kategori terampil menjadi 87,5\% kategori sangat terampil.

Berdasarkan pengamatan dari hasil pengamatan aktivitas mengajar guru mengalami peningkatan, guru membimbing siswa dalam menerapkan model dan mengklarifikasi nilai dalam mengambil keputusan dalam konflik.. Hal ini merupakan keberhasilan yang diperoleh guru dalam menerakan model klarifikasi nilai tipe VCT-Games dengan mengikuti langkah-langkah mengembangan skenario pembelajaran, membuka pelajaran dengan menjelaskan tujuan pembelajaran, metode kerja, mengutarakan stimulus, membantu siswa mengklarifikasi nilai, mengomentari dan mendiskusikan, serta memantapkan nilai yang dapat diambil dari materi (Sanjaya, 2008: 61).

Keterampilan pengambilan keputusan siswa dalam penerapan model dilihat dari aktivitas siswa yang telah mampu memahami konflik, menganalisis pilihan dalam mengatasi konflik, mengklarifikasi nilai konflik, dan mengambil keputusan dalam mengatasi konflik. Aspek-aspek yang diamati tertuang dalam lembar observasi aktivitas siswa sesuai dengan indikator keterampilan pengambilan keputusan yang dikemukakan oleh Widodo (2009) mengidentifikasi resiko permasalahan, mengidentifikai dan menganalisis pilihan-pilihan, menganalisis informasi dengan mengklarifikasi nilai, dan menentukan pilihan dengan mengambil keputusan.

Peningkatan hasil tes keterampilan pengambilan keputusan skor rata-rata kelas pra siklus 67, mengalami peningkatan pada siklus 1 yaitu 73, siklus 2 meningkat menjadi 77, dan siklus 3 meningkat menjadi 81. Selain dari itu ketuntasan belajar disetiap siklus mengalami peningkatan yaitu pada pra siklus 20\% dikategorikan kurang terampil dengan jumlah siswa tuntas 8 siswa, pada siklus 1 memperoleh hasil 45\% dikategorikan cukup terampildengan jumlah siswa tuntas 18 siswa, siklus 2 memperoleh hasil 75\% 
dikategorikan terampil dengan siswa tuntas 30 siswa, dan siklus 3 87,5\% dikategorikan sangat terampil dengan siswa tuntas 35 siswa.

\section{E. KESIMPULAN DAN SARAN}

\section{Kesimpulan}

Berdasarkan hasil penelitian dan pembahasan maka peneliti memiliki kesimpulkan sebagai berikut:

a. Penerapan model klarifikasi nilai pada pembelajaran IPS di kelas VIII H MTsN 2 Cirebon sudah berhasil dan dapat diterapkan oleh guru mata pelajaran IPS. Pada siklus 1 aktivitas guru memperoleh persentase 72\% dikategorikan cukup. Siklus 2 menunjukan aktivitas guru memperoleh persentase $84 \%$ dikategorikan baik. Hasil siklus 3 menunjukan aktivitas guru memperoleh persentase 90\% dikategorikan sangat baik.

b. Keterampilan pengambilan keputusan siswa tentang konflik sosial dengan penerapan model klarifikasi nilai telah berhasil membuat siswa lebih aktif dalam pembelajaran IPS. Siswa aktif dalam pembelajaran, percaya diri untuk memberikan klarifikasi nilai serta dapat mengambil keputusan tentang konflik sosial.Hal ini dilihat dari hasil observasi aktivitas belajar siswa pada siklus 1 menunjukan aktivitas belajar siswa memperoleh persentase 55\% dikategorikan kurang. Pada siklus 2 aktivitas belajar siswa memperoleh persentase 74\% dikategorikan cukup dan observasi siklus 3 aktivitas belajar siswa memperoleh persentase $80 \%$ dikategorikan baik.

c. Peningkatan Hasil Tes keterampilan pengambilan keputusan tentang konflik sosial dengan penerapan model klarifikasi nilai mengalami peningkatan yang signifikan disetiap siklusnya. Hal ini dapat dilihat dari peningkatan skor rata-rata kelas yang meningkat dari pra siklus 67, siklus 1 rata-rata kelas 73, siklus 2 rata-rata kelas 77, dan siklus 3 ratarata kelas 81. Selain dari itu ketuntasan belajar disetiap siklus mengalami peningkatan yaitu pada pra siklus 20\% dikategorikan kurang terampil, siklus 1 45\% dikategorikan cukup terampil, siklus 2 75\% dikategorikan terampil, dan siklus 3 87,5\% dikategorikan sangat 
terampil. Siswa tidak tuntas diberi remidial. Adapun jumlah peningkatan dari setiap siklusnya yaitu skor rata-rata kelas 11 dan peningkatan jumlah ketuntasan dari siklus 1-3 yaitu 67,5\%.

\section{Saran}

Berdasarkan hasil penelitian dan pembahasan maka saran yang diberikan yaitu sebagai berikut:

a. Model klarifikasi nilai terbukti dapat meningkatkan keterampilan pengambilan keputusan tentang konflik sosial. Diharapkan guru dapat mendesain model pembelajaran ini dengan efesien da efektif sehingga dapat membuat pembelajaran IPS lebih menarik dan memunculkan keterampilan- keterampilan siswa.

b. Guru diharapkan untuk membuat pembelajaran IPS menjadi lebih menarik dengan menggunkan model-model yang dapat meningkatkan keterampilan siswa seperti halnya model klarifikasi nilai yang dapat meningkatkan keterampilan pengambilan keputusan siswa.

c. Sekolah diharapkan dapat meningkatkan dan memperbaiki sarana dan prasarana sebagai penunjang proses pembelajaran agar pembelajaran menjadi lebih kondusif dan menyenangkan sehingga dapat meningkatkan keterampila-keterampilan belajar siswa.

\section{DAFTAR PUSTAKA}

Arifin, Zaenal. 2011. Penelitian Pendidikan Metode dan Paradigma Baru. Bandung: Remaja Rosdakarya

Arikunto, Suharsimi. 2006. Prosedur Penelitian Suatu Pendekatan Praktek. Jakarta: Rineka Cipta.

Arini, Neni Setia. 2014. Pengaruh Model Kalrifikasi Nilai Berbasis Jurnal Terhadap Proses Internalisasi Nilai Dalam Pembelajaran IPS. Bandung: Tesis.

Gunawan, Rudi. 2013. Pendidikan IPS Filosofi, Konsep dan Aplikasi. Bandung: Alfabeta.

Kunandar. 2013. Langkah Mudah Penelitian Tindakan Kelas. Depok: Raja Grapindo Persada.

Muslimah, Erni. dkk. 2017. Meningkatkan Hasil Belajar dan Keterampilan Mengambil Keputusan dengan Penerapan POE pada 
Materi Hidrolisi garam kelas XI-MIA 2 MAN KELUA Tahun Pelajaran 2016/2017. Jurnal of Chemistry And Education. Vol.1, No.1 hal 46-51.

Riduan. 2007. Belajar Mudah Penelitian Untuk Guru, Karyawan, Dan Peneliti Pemula. Bandung: Alfabeta

Rofiq, Arif Ainur. 2015. Pentingnya Keterampilan Pengambilan Keputusan Sosial Bagi Siswa SMP. Jurnal Ilmu Psikologi, Vol.2 No 2, hal 175-184.

Sanjaya, Wina. 2008. Strategi Pembelajaran: Berorientasi Standar Proses Pendidikan. Jakarta: Kencana Prenada Medi Grup.

Siregar, Eveline dan Hartini Nara. 2011. Teori Belajar dan Pembelajaran. Bogor: Ghalia Indonesia

Soetopo, Hendyat. 2012. Perilaku Organisasi. Bandung: Remaja Rosdakarya.

Sudaryono. 2014. Classroom Action Research. Jakarta: Lentera Ilmu Cendekia

Sudjana, Nana. Penilaian Hasil Proses Belajar Mengajar. Bandung: Remaja Rosdakarya.

Sutarjo, Adisusilo. 2013. Pembelajaran Nilai- Karakter Kontruktivisme dan VCT Sebagai Inovasi Pendekatan Pembelajaran Efektif. Jakarta: Raja Grafindo Persada.

Widodo, Wahono. 2009. Keterampilan pengambilan keputusan pada https://vahonov.files.wordpress.com/2009/07/keterampilanpengambilan- keputusan.pdf. diakes pada 25 September 2017 pukul 11.25 . 